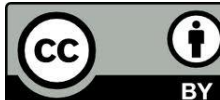

\title{
UMA NOVA ORDEM RELIGIOSA: O NASCIMENTO DA COMPANHIA DE JESUS EM TEMPO DE REFORMAS RELIGIOSAS
}

New religious order: the birth of the Society of Jesus in religious reforms times

Luiz Antonio Sabeh Universidade Federal de Alfenas e-mail: luiz.sabeh@gmail.com

RESUMO: A Companhia de Jesus foi uma das instituições mais atuantes e influentes do mundo ocidental durante a Época Moderna. Entre os muitos aspectos de sua história, alguns polêmicos, seu nascimento como uma entidade de poder encontra explicações discordantes na historiografia. A partir da análise dos documentos relativos à criação e aprovação da ordem religiosa, e de alguns documentos do universo religioso do período, este artigo tem como objetivo refletir sobre essas explicações. Pretende-se, com isso, entender como o ambiente de reformas religiosas do Velho Continente influenciou no nascimento da ordem jesuítica e, igualmente, como o seu funcionamento impactou nesse mesmo processo que a originou.

Palavras-chave: Igreja Católica ; Companhia de Jesus ; Reformas Religiosas.

ABSTRACT: The Society of Jesus was one of the more active and influent institutions of the occidental world during the Modern Era. Among many aspects of the history to this Society, some controversial, its birth as power organization encountered many discordant explanations in its historiography. From the analysis of the documents related to the creation and approbation of the religious order, and some documents of the religious universe from this period, this article has the aim of think about these explanations. It is pretended to understand how the religious reforms from the Old Continent influence the Society of Jesus birth as well the impact of this congregation functionality in the same process that give rise to it.

Keywords: Catholic Church, Society of Jesus, Religious Reforms. 


\section{Introdução}

Criada na década de 1530 e aprovada pela Santa Sé em 1540, a Companhia de Jesus tornou-se uma das ordens religiosas mais atuantes do mundo católico e uma das instituições mais influentes do mundo ocidental até, pelo menos, meados do século XVIII. Polêmica, por sua história perfilam conflitos que, matizados pelos olhares dos seus contrários, em seu tempo e depois, moldaram preconceitos e estigmas. Desde a época de sua aprovação, a ordem religiosa foi alvo de críticas ferrenhas de outras congregações católicas e de vários seguimentos sociais que não viam com bons olhos os benefícios que a ordem recebia dos poderes políticos e religiosos para levar a cabo suas atividades. Esses, evidentemente, foram apenas alguns dos muitos opositores que a ordem jesuítica ganharia com o passar do tempo, e os mais importantes talvez tenham sido os protestantes e os iluministas, que baseavam suas críticas à intolerância religiosa da Igreja Católica na conduta e nas práticas religiosas da ordem e do Santo Ofício da Inquisição. Em diferentes locais e momentos, os membros da Companhia de Jesus também protagonizaram vários escândalos. Por conta do envolvimento em querelas que envolviam o alto escalão político da Europa e inúmeras suspeitas de participação em conspirações, muitos inacianos foram alvos da própria Inquisição e das mesmas Coroas que, no século XVI, haviam contribuído para a institucionalização, fortalecimento e crescimento da Companhia de Jesus. ${ }^{1}$

Mas, não foram apenas os escândalos que fizeram da Companhia de Jesus $a$ ordem religiosa da sua época. A imensa capacidade dos inacianos de se embrenharem em mundos incógnitos para propagar o cristianismo, as inovações no âmbito da evangelização e da educação que daí resultaram e o legado cultural que seus membros deixaram também explica o papel de vanguarda exercido pelos jesuítas na Europa e no Novo Mundo. ${ }^{2}$

Um dos aspectos mais marcantes da história da Companhia de Jesus é, sem dúvida, sua rápida afirmação enquanto instância de poder político e religioso do mundo cristão. E as explicações para isso são pouco teorizadas porque o contexto do seu nascimento apresentam fatos que são, muitas vezes, entendidos como postulados

\footnotetext{
${ }^{1}$ Sobre estas questões ver ASSUNÇÃO, 2004, pp. 105-120; e, na íntegra, WRIGHT, 2006; e FRANCO; TAVARES, 2007.

${ }^{2}$ Exemplos da participação dos jesuítas no campo das artes, letras, educação, ciência, e também no âmbito político do Brasil Colonial podem ser vistos em CALMON, 1963, pp. 935-966; HOLANDA, 2008, pp. 101-162; e HOLANDA, 2003, pp. 59-102.
} 
flagrantes que respondem a questão. Afinal, a ordem religiosa foi criada no bojo de profundas transformações pela qual passava a Europa dos Quinhentos: de um lado o crescimento da "heresia" reformista do protestantismo, que exigiu da Igreja Católica o recrudescimento de uma reforma já em curso; de outro, a abertura promovida pelas Coroas ibéricas de mundos novos habitados por seres tidos como "pagãos", o que avivou o dever apostolar dos monarcas católicos de levar-lhes a Boa Nova e, consequentemente, deflagrou um projeto evangelizador de proporções globais.

Tradicionalmente, a historiografia explica que, diante desse cenário, a Igreja Católica firmou as bases da Reforma Católica (ou Contrarreforma), a partir do século XVI, na restruturação das bases da fé (atividade do Concílio de Trento), na vigilância contra os hereges (atividade da Inquisição) e no missionarismo (atividade da Companhia de Jesus). ${ }^{3}$ Autores que adotam esta perspectiva entendem que a ordem jesuítica foi criada pela Santa Sé para atuar como ponta-de-lança de seu processo reformista porque, de fato, ela atuou massivamente na construção de um império cristão no Novo Mundo e na defesa do bloco católico no Velho Continente.

No entanto, alguns historiadores defendem a tese de que a Companhia de Jesus não foi criada para servir à reforma da Igreja Católica, porque entendem que a ordem nasceu do anseio do seu fundador, Inácio de Loyola, de atuar na Cruzada, um projeto vivo para os europeus dos Quinhentos que ainda enxergavam a possibilidade de expulsar os turco-otomanos de Jerusalém. ${ }^{4}$

Ora, quais teriam sido as razões que levaram à criação da Companhia de Jesus? O contexto em que nasceu a ordem religiosa ajuda, de fato, a explicar porque ela já surgiu poderosa e capaz de levar a cabo as reformas políticas e religiosas do mundo católico no século XVI?

O objetivo deste artigo é responder ou, ao menos, refletir sobre essas questões, o que nos leva, evidentemente, a um mergulho no ambiente político-religioso que banhava a Europa quando do surgimento da Companhia de Jesus e, igualmente, nos pontos inerentes à sua criação e aprovação pela Santa Sé enquanto entidade habilitada a executar parte da Reforma Católica ou, como comumente se chama, a Contrarreforma.

\footnotetext{
${ }^{3}$ A exemplo dessa abordagem, muito comum em livros didáticos de História para o Ensino Fundamental e Médio, ver SIQUEIRA, 1998, pp. 14-15.

${ }^{4}$ Entre eles destacam-se O'MALLEY, 2004; e WRIGHT, 2006.
} 


\section{Uma nova ordem religiosa: reformas religiosas}

A Igreja Católica Apostólica Romana enfrentava, desde a Baixa Idade Média, uma série de crises. No século XIII, as seitas dos albigenses romperam as fronteiras da França e chegaram até os Países Baixos, Lombardia e regiões da atual Espanha. Por pregarem a insubordinação material e espiritual contra a Igreja de Roma, foram perseguidos pelo Santo Ofício da Inquisição, criado em 1215 para este fim. No seio da própria Santa Sé, a ordem franciscana nasceu para celebrar a pobreza como valor cristão, em oposição à riqueza e ostentação das igrejas. Entre 1378 e 1417, o processo que resultou no Grande Cisma do Ocidente viria a abalar definitiva e profundamente a estrutura da Mater Ecclesia (DELUMEAU, 2004, pp. 107-132; e TAVARES, 2004, pp. 87-140).

Paralelamente a estes acontecimentos, as práticas religiosas, principalmente o culto exterior dos sacramentos que marcavam as passagens da vida dos fieis, paulatinamente combinavam-se com os inúmeros elementos culturais não-cristãos presentes na Europa. Gradativamente, as práticas cristãs beiravam ao paganismo, principalmente porque o clero, além de não interferir para manter o zelo dos dogmas católicos, também participava das religiões “populares”, uma expressão da sua carência de vocação sacerdotal e da sua má formação (DELUMEAU, 2004, pp. 107-132; GREEN, 1991, pp. 123-143; MULLETT, 1985, pp. 07-20; VAINFAS, 1997, pp. 07-45; e TAVARES, 2004, pp. 87-140).

Nesse cenário de crise, a Europa assistiu a diferentes formas de reação. No século XIV, a peste que assolava o continente era vista como uma resposta de Deus ao desregramento moral da cristandade e, por isso mesmo, o sinal do fim dos tempos. $\mathrm{O}$ medo da morte e do fim mundo deu origem a movimentos religiosos e a ondas de peregrinações que exprimiam, de acordo com Michel Mullett, a renovação da piedade cristã e a regeneração religiosa pessoal (1985, pp. 13-20). É desse período, por exemplo, a Devotio Moderna, movimento que sugeria a meditação, a interiorização dos preceitos religiosos e a difusão do cristianismo pela multidão leiga. Para além de questionarem os dogmas da Igreja, seus adeptos buscavam uma reaproximação com os preceitos religiosos do cristianismo e contavam, para isso, com inúmeras obras surgidas no período que ensinavam como imitar a vida de Cristo. Traduziam-se, por isso mesmo, 
como manuais de salvação que exprimiam não uma crise na instituição Igreja, mas na sensibilidade religiosa que resgatava questionamentos sobre o papel da religião e, igualmente, do homem diante da religião (DELUMEAU, 2004, pp. 107-132; e MULLETT, 1985, pp. 07-20).

No entanto, em um momento em que a Igreja representava o lugar da salvação, seu colapso institucional agravava esse quadro mais amplo de crise da sensibilidade religiosa, porque a Santa Sé não era capaz de conter o distanciamento do rebanho cristão dos preceitos da fé e, tampouco, de oferecer a redenção a uma humanidade que se via acuada pelo castigo divino.

Não tardou, então, para que esta situação se fizesse sentir também no meio letrado. O desenvolvimento da imprensa e a presença de professores italianos em grandes universidades da Europa possibilitaram que filósofos humanistas difundissem suas teses nas regiões das atuais França, Inglaterra e Alemanha. Do mesmo modo que eles propunham novas funções para a Filosofia, também lançavam novos olhares sobre a Justiça, sobre o Estado e sobre a Educação. A tentativa desses homens do Renascimento era romper com os métodos e temas de estudo da Escolástica, principalmente as interpretações que esses faziam do Direito Romano e dos fundamentos do Estado. Daí nasceram obras que teorizavam o papel dos governantes na gerência do bem comum e a militância pela inserção do estudo das humanidades na grade curricular dos centros de formação intelectual dos governantes a fim de que esses adquirissem as virtudes necessárias para o "bom governo" (REALE; ANTISERI, 1990, pp. 16-318; e SKINNER, 1996, pp. 213-281).

Além disso, os humanistas também propunham uma nova maneira de se estudar os textos bíblicos a fim de se ter uma visão mais racionalista da religião e, assim, romper com o obscurantismo que envolvia as interpretações dos dogmas do cristianismo defendidas pela Igreja. De suas penas nasceram textos que traziam novas abordagens sobre a exegese e comentários bíblicos que visavam recuperar o contexto histórico das doutrinas cristãs com o objetivo de explicá-las a partir dos elementos que lhe eram particulares, e não para delas extrair argumentos que legitimassem as lições e os artigos de fé, como faziam os escolásticos. Esses estudos, que versavam principalmente sobre os princípios teológicos da salvação e sobre o Novo Testamento, fundamentavam-se em novas e sistemáticas traduções dos textos bíblicos originais escritos em grego e em 
hebraico (REALE; ANTISERI, 1990, pp. 16-318; e SKINNER, 1996, pp. 213-281).

O espírito que envolvia o studia humanitatis fazia com que seus entusiastas tentassem enxergar o homem e mundo sem as lentes do dogmatismo religioso. Como explicou Lucien Febvre, não se tratava de ceticismo, descrença ou ateísmo, porque eles não questionavam a existência de Deus e a necessidade de salvação do homem, mas sim as explicações não racionais formuladas pela Igreja sobre a origem do homem, do universo e dos seus dogmas e a forma arbitrária como ela impunha sua visão de mundo (2009, pp. 386-394).

Pelo fato dos humanistas entenderem que viviam um momento de crise e que precisavam rever os conceitos que regiam o comportamento do homem e a vida em sociedade, não tardou para que grandes pensadores começassem a questionar o estado de penúria moral do clero e sua consequente ineficiência de conduzir a cristandade à vida ensaiada pelo Evangelho. Daí resultou tanto os ferrenhos ataques literários dirigidos à Igreja quanto propostas de inovação do sacerdócio e das práticas religiosas. A obra Elogio da Loucura, de Erasmo, enquadra-se perfeitamente neste cenário dramático de críticas ao estado moral da cristandade:

\footnotetext{
É dessa forma que pretendem ser, como dizem eles, os nossos apóstolos, com toda a sua imundície, toda a sua ignorância, toda a sua grosseria, todo o seu descaramento (...). O mais ridículo, a meu ver, são os que se horrorizam ao verem dinheiro, como se se tratasse de uma serpente, mas não dispensam o vinho nem as mulheres. Não podeis, enfim, imaginar quanto se esforçam por se distinguirem em tudo uns dos outros. Imitar Jesus Cristo? É o último dos seus pensamentos (ROTERDÃ, 1959, pp. 129-130).
}

Assim como Erasmo se referia aos clérigos com a ironia e o sarcasmo, François Rabelais utilizou-se da literatura para criticar, veementemente, o comportamento, a moral e as instituições da França Moderna. Suas "denúncias" abarcavam a sociedade como um todo, o que não deixava de fora a condição do clero. Os cinco livros que mais tarde compuseram a obra Gargântua e Pantagruel circularam ao longo da década de 1530 e atacavam, entre outros aspectos, a vida monástica e os abusos cometidos pela Santa Sé que Lutero já havia questionado. O autor despojava, sem pudor, os segredos "imorais" das pessoas que o cercavam, clérigos em sua maioria. Esses eram representados pela personagem frei Jean, que aparece em vários capítulos. São, portanto, vários os ataques ao comportamento desses homens de fé. Em uma de suas falas, o frade advertiu os peregrinos que, ao saírem em romaria, deixavam suas esposas 
aos cuidados dos monges: "basta[va] a sombra da torre de um convento para [elas] engravidar[em]" (RABELAIS, 2003, p. 189), porque os frades eram "vagabundos, (...) fingidos, hipócritas, beatos e outras seitas de gente que se disfarça como mascarados para enganar todo o mundo" (idem, ibidem, p. 382). Por trás de suas falsas vidas devotas, "passa[v]am à tripa forra, Deus sabe qual, et Curiós simulant, sed Bacchanalia vivunt" (idem, ibidem, p. 383). ${ }^{5}$

Com ou sem esta personagem, Rabelais não deixou de chamar os heréticos de carne assada, satirizando a fogueira da Inquisição. Mencionou que os ladrões, os falsificadores, bem como os advogados prevaricadores estavam do lado dos diabos, e os estudantes e advogados eram protegidos por Lúcifer. Os frades eram o prato predileto do rei dos diabos, pois eles esqueciam de recomendar a si mesmos nos sermões. Quanto ao papa, o autor o comparou com o diabo ao se referir que o seu grão na terra é morto e comprido, sua corrupção é hereditária e és maldito no Evangelho. Ainda, satirizou o Sumo Pontífice devido sua figura onipotente e suas raras aparições em público. Segundo o autor, para esconder sua cara patética e a vergonha do seu ofício. Panúrgio, uma das personagens de Rabelais, ficou diante do Vigário e "curiosamente contemplou sua forma, seus gestos e sua atitude. Depois exclamou em voz alta dizendo: 'Não está bem o bicho; parece uma poupa (...)... Sim, é bem uma poupa"” (RABELAIS, 2003, p. $820){ }^{6}$

Mas, diferentemente dos humanistas, os adeptos da Devotio Moderna propuseram reformas que preparassem o clero para o exercício pastoral e que estimulassem a devoção apostólica para, enfim, aproximar a Igreja do seu rebanho. Entre eles estavam Lutero, Calvino, Inácio de Loyola, entre outros. O que diferia suas proposições, além do tempo e do espaço onde ocorreram, eram o teor e intensidade com que sugeriam essas transformações. Enquanto Loyola reunia-se com companheiros na França para estudar a fundação de uma nova ordem religiosa, Lutero e Calvino colocavam em xeque os dogmas católicos e negavam a autoridade papal, ou seja, suas propostas implicavam profundas reformas, também, dos costumes e da moral

\footnotetext{
${ }^{5}$ A frase em latim significa, de acordo com o tradutor de Gargântua e Pantagruel (2003), "fingem ser Curiós, mas vivem nas bacanais".

${ }^{6}$ Segundo o tradutor da obra de Rabelais (2003), "poupa" era termo do francês moderno que significava "pessoa que se deixa enganar, pateta". As críticas feitas ao clero e ao papa podem ser vistas ao longo dos capítulos XLIV e LIV do Quarto Livro (pp. 721-754); e dos capítulos I ao VIII do Quinto Livro (pp. 799$823)$.
} 
estabelecida. Daí Ronaldo Vainfas afirmar que protestantes e católicos partilhavam de um passado comum que havia afastado os cristãos dos preceitos morais da vida religiosa. O historiador observou que

\begin{abstract}
Os intelectuais de inícios do século XVI mostravam-se sobremodo inquietos com a decadência da cristandade, e desejavam com ardor aproximar a humanidade de Deus, qualquer que fosse a luta a ser travada com o Demônio. Tal foi a substância do Humanismo Cristão e, consequentemente, a da Reforma e da Contrarreforma, do que resultou um vasto e ambicioso programa de evangelização de massas em todos os domínios da vida social e religiosa (VAINFAS, 1997, p. 09).
\end{abstract}

Nesta contenda de almas, as reformas religiosas nasceram de um mesmo processo de longa duração da renovação do cristianismo. A mudança que Lutero propunha, entretanto, marcaria singularmente as reformas institucionais da Santa Sé.

O padre agostiniano publicou, em outubro de 1517, suas 95 teses para protestar contra os abusos materiais e morais exercidos pela Igreja de Roma. Frente ao declínio da vida monástica - decorrente da venda de indulgências, do descaso com a distribuição dos sacramentos e com os locais de culto, entre outros abusos - Lutero percorreu as regiões das atuais Alemanha, Suécia, Dinamarca, Noruega e França pregando uma doutrina de reivindicação à reforma na Igreja. O padre dissidente defendia a ideia de que a salvação do homem não deveria ser buscada com obras ou pagamentos, e esta foi a questão central do seu rompimento com a Santa Sé (SABEH, 2009, pp. 27-39).

Na tradição cristã, o homem só é salvo quando recebe os sacramentos da Santa Sé, porque esses assinalam à justificação do pecado, que é a graça salvadora de Deus. O batismo, por exemplo, justifica o pecado original. Isso porque os teólogos préagostinianos haviam instituído a Igreja e os seus sacramentos como os veículos que levam a graça da salvação de Deus aos homens. Nos primórdios do cristianismo, a salvação cristã era expressa na relação pessoal Cristo-Verbo e criatura. Porém, no século III, Cipriano influenciava-se pelo contexto cultural romano que exaltava o valor das instituições e teorizou a salvação cristã fundamentada no binômio institucional Cristo-Igreja, e não pessoal: "fora da Igreja não há salvação". A Igreja, a partir de então, passou a apresentar-se como local de salvação, e esta oferecida pelos seus sacramentos, atividades e o modo de vida por ela definido, já que Cipriano atribuía a Cristo a autoria da salvação (GROSSI; SESBOÜÉ, 2003a, pp. 229-274; LADARIA, 2003, pp. 35-85). 
Se Jesus vivia na Igreja, ela era, então, a via de salvação dos homens. Os seus sacramentos, por comunicarem a salvação de Cristo, tornaram-se em instituições salutares, e os bispos, em mediadores da salvação, pois que os administradores dessas instituições.

A salvação do homem, para Lutero, encontrava sua origem na doutrina que elaborou acerca da justificação do pecado original. A indulgência oferecida pela Igreja era uma forma de justificação do pecado pela obra, e Lutero entendia que, se o homem recebera uma graça de Deus, a justificação do seu pecado se daria por sua fé em Cristo. Esta era a forma de Jesus imputar sua justiça ao homem que, ao pecar, cometia injustiça à graça que recebera. Nesse sentido, sua concepção de justificação rompia com a tradição dos teólogos latinos de que a Igreja e seus sacramentos eram instituições de salvação. O padre de Wittenberg fundamentava-se nas epístolas de Paulo para demonstrar que a salvação do homem era cedida pela graça de Jesus, e não conquistada com o pagamento, à Igreja, de bens materiais. O seu pecado, pois, era justificado pela graça de Deus, que lhe dava a salvação por sua extrema bondade e misericórdia (GROSSI; SESBOÜÉ, 2003b, pp. 275-311). A graça da salvação, nesse caso, era uma concessão de Deus aos mortais ou, em outras palavras, uma obra de Deus, e não do homem, como escrevera o apóstolo:

Porque é gratuitamente que fostes salvos mediante a fé. Isto não provém de vossos méritos, mas é puro dom de Deus. Não provém das obras, para que ninguém se glorie. Somos obra sua, criados em Jesus Cristo para as boas ações, que Deus de antemão preparou para que nós as praticássemos (BÍBLIA. N. T. Ef., 2, 4-10).

A ideia luterana de justificação do pecado, como se observa, manifestava sua oposição à venda de indulgências porque a salvação, como pregava, decorria da confiança em Deus e não dos sacramentos e penitências da Igreja. Embora Lutero não tivesse o intuito de fundar uma nova religião, mas sim reformar a Igreja romana, acabou por romper com o papado ao negar a sua autoridade. Os princípios do protestantismo residia, pois, na anulação do celibato, da negação ao culto a Nossa Senhora e santos, bem como o uso do latim nas missas e dos sacramentos, com exceção do batismo e da comunhão (GROSSI; SESBOÜÉ, 2003b, pp. 275-311). Suas teses, quanto a este último aspecto, apontavam para o fato de que os fiéis não precisavam da Igreja para conquistar sua salvação. 
Os dissidentes, nesse sentido, agravaram o quadro de crise institucional da Igreja. No longo processo de renovação do cristianismo, as teses protestantes de Lutero, Calvino, Zwinglio, entre outros, evidenciavam a necessidade urgente de transformações na estrutura religiosa do Velho Continente. Diante das dúvidas que se colocava sobre a salvação das almas, a Santa Sé precisava consolidar a doutrina definida, assegurar a unidade religiosa e trabalhar no fazimento de novos cristãos para recuperar os fiéis perdidos às novas religiões que nasciam na Europa.

De fato, o movimento conhecido como Contrarreforma manifestou as inquietações da Santa Sé em estabelecer diretrizes para a conduta do clero e do seu rebanho; em determinar qual comportamento ou doutrina eram aceitas e quais eram contrárias e perniciosas aos preceitos da fé; e, também, na reeducação religiosa da cristandade e no fazimento de novos cristãos. É por isso que historiadores como Michel Mullett (1985, p. 17) e Sônia Siqueira (1998, p. 15) concordam que, do ponto de vista institucional, a Reforma Católica assentou-se na convocação do Concílio Ecumênico de Trento, na restruturação dos bispados e no uso de instituições capazes de promover a reestruturação das bases da fé, a vigilância contra os hereges e o missionarismo.

Diante do avanço do protestantismo na Europa, o papa Paulo III convocou, em 13 de dezembro de 1545, um concílio ecumênico na cidade de Trento a fim de reafirmar a doutrina católica quanto aos dogmas bíblicos, sacramentos, obrigações religiosas, culto dos santos e indulgências, entre outras questões dogmáticas e disciplinares que os concílios anteriores não haviam definido. Após 25 sessões (interrompidas várias vezes por diversas razões), sob a presidência do papa Pio IV, em 4 de dezembro de 1563, a estrutura da Igreja havia sido reformada em todos os seus níveis: ao mesmo tempo em que reafirmava os valores católicos na sociedade, invalidavam-se as teorias protestantes (SABEH, 2009, pp. 29-31).

A documentação deste concílio deixa transparecer as aspirações da Santa Sé: combater as heresias protestantes e reafirmar os dogmas questionados pelos reformados. Já no seu primeiro período, compreendido entre 1545 e 1547, foram realizadas dez sessões onde se estabeleceu, entre outros, decretos sobre o pecado original, a salvação 
(justificação), e os sacramentos da Santa Sé, exatamente os preceitos impugnados por Lutero (APOSTOLADO, s/d, $1^{\circ}$ Período). ${ }^{7}$

Em sua quinta sessão, de 17 de junho de 1546, foi instituído o decreto sobre o pecado original "para que não flutue no povo cristão todos os ventos de novas doutrinas" (APOSTOLADO, s/d, $1^{\circ}$ Período, Sessão V, p. 01). Neste documento foi declarado, entre outros, que seria excomungado aquele que não acreditasse que o pecado original era uma herança do pecado de Adão, numa alusão à ideia luterana de que o nascimento marcaria a presença contínua de Deus na Terra. O batismo também perfila por suas páginas, sempre referindo ao único meio pelo qual o homem é tirado do seu estado de pecado original, porque, segundo a Igreja, "não existe outro nome entre os homens da terra, em que se possa obter a salvação" (APOSTOLADO, s/d, $1^{\circ}$ Período, Sessão V, p. 01).

Em 13 de janeiro de 1547, na sexta sessão, foi divulgado o decreto sobre a salvação, ou a justificação dos pecados. A alegação da cúria romana?

\begin{abstract}
Havendo-se difundido nestes tempos, não sem a perda de muitas almas e grave corrosão na unidade da Igreja, certas doutrinas errôneas sobre a Salvação, o Sacrossanto, Ecumênico e Geral concílio de Trento (...) se propõe declarar a todos os fiéis cristãos, pela honra e glória de Deus Onipotente, para tranquilidade da Igreja e salvação das almas, a verdadeira e perfeita doutrina da salvação (APOSTOLADO, s/d, $1^{\circ}$ Período, Sessão VI, p. 01).
\end{abstract}

Baseados no apóstolo Paulo, mesma fonte de inspiração de Lutero quando de sua redação da doutrina da justificação, os conciliares definiram que a justiça de Cristo não se dava pela fé, mas através dos sacramentos da Igreja, uma evidente manobra de legitimação destes como as instituições salutares dos homens. Novamente o batismo aparece no texto como o sacramento que garante a salvação primeira, ou seja, que justifica o pecado original, nomeada não por outra razão de "primeira justificação".

\footnotetext{
7 A documentação do Concílio de Trento aqui analisada foi compilada pelo Apostolado Veritatis Splendor. Trtata-se de APOSTOLADO Veritatis Splendor (org.). Documentos do Concílio Ecumênico de Trento. $1^{\circ}$ Período (1545-1547); $2^{\circ}$ Período (1551-1552); $3^{\circ}$ Período (1562): Bula Convocatória do Concílio e Sessões de I a X; Bula de Reinstalação do Concílio e Sessões de XI a XVI; Bula de Reinstalação do Concílio, Sessões de XVII a XXV, Finalização do Concílio, Admoestações aos Padres, Confirmação do Concílio e Apêndices. Direção de Carlos Martins Nabeto e tradução de Dercio Antonio Paganini. Disponível em http://www.veritatis.com.br/doutrina/documentos-da-igreja. Acesso em 21/12/2012. Nota-se que a paginação do documento não é sequenciada. A cada sessão, a paginação se inicia em 01.
} 
No quarto capítulo do documento oriundo desta sessão, a Santa Sé instituiu que a salvação "não se pode conseguir (...) sem o batismo, (...) segundo o que está escrito: 'Não pode estar no Reino dos Céus, ninguém que não tenha renascido pela água e pelo Espírito Santo"” (APOSTOLADO, s/d, $1^{\circ}$ Período, Sessão VI, p. 02). Dez capítulos adiante determinou-se que, tendo o justo recebido a graça da salvação e caído em pecado, poderia "novamente salvar-se pelos méritos de Jesus Cristo, procurando, estimulados com o auxílio divino, recobrar a graça perdida, mediante o sacramento da Penitência" (APOSTOLADO, s/d, $1^{\text {o }}$ Período, Sessão VI, p. 06).

Isto explica porque o batismo, para a Igreja, garantia a salvação denominada de "primeira justificação". Primeira porque, uma vez batizado, o indivíduo deveria levar uma vida cristã para justificar a graça da salvação recebida. Deveria, pois, ser vigilante em sua conduta, baseando-se nos mandamentos de Deus, como afirma a documentação do concílio. A segunda justificação só ocorreria caso o indivíduo voltasse ao pecado depois de receber o batismo. Seria, nesse caso, justificado através do sacramento da penitência, instituído por Cristo para oferecer sua graça da salvação àquele que não mais poderia receber o batismo para se livrar do seu estado de pecado.

Por esta razão, e para assegurar os sacramentos como via de salvação para a humanidade - legitimando a necessidade que os homens tinham da Igreja, portanto - na sétima sessão do concílio, de 03 de março de 1547, foi instituído o decreto sobre os sacramentos, com a expressa finalidade

de dissipar os erros e extirpar as heresias, que atualmente apareceram acerca dos Santos Sacramentos, em parte devido às antigas heresias já condenadas pelos Padres, e em parte por aquelas que foram inventadas recentemente, que são ao máximo perniciosas à pureza da Igreja Católica, e à salvação das almas (APOSTOLADO, s/d, $1^{\circ}$ Período, Sessão VII, p. 01).

O documento instituía, entre outros, que seria excomungado aquele que não acreditasse que os Sacramentos haviam sido estabelecidos por Jesus: o batismo, a confirmação (crisma), a eucaristia, a penitência (confissão), a extrema-unção, a ordem e o matrimônio. No IV Cânon dos sacramentos comuns, a mesma pena era dada àquele que dissesse "que os Sacramentos da nova lei não são necessários, porém supérfluos para a salvação, e que os homens sem eles e sem o desejo deles, alcançam de Deus, apenas pela fé, a graça da salvação" (APOSTOLADO, s/d, $1^{\circ}$ Período, Sessão VII, p. 01). A Igreja reforçava, ainda, a importância do batismo para as doutrinas da criação e 
da justificação contestadas por Lutero, aplicando a excomunhão, no V Cânon sobre o batismo, para quem dissesse que "o batismo é arbitrário, isto é, não é necessário para

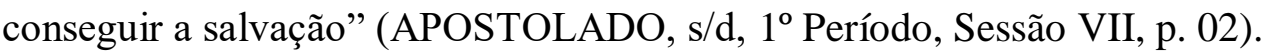

Em linhas gerais, as sessões do concílio de Trento aqui comentadas emergem a reflexão de que o papado manifestou fortemente sua preocupação em invalidar as teorias perniciosas aos preceitos católicos, como, também, em legitimar a Igreja como instrumento salvífico, o que exprimia a dependência dos homens a essa instituição, também questionada pelos protestantes. E essa mesma preocupação que o concílio apresentou com a "redenção" da humanidade esteve presente nas demais ações da Reforma Católica que, por isso mesmo, transfigurou-se como uma nova ordem religiosa dos tempos modernos.

No intuito de levar a doutrina reafirmada em Trento para os recônditos das comunidades cristãs europeias, e ao mesmo tempo compelir a cristandade à prática de um catolicismo ortodoxo, a Igreja Católica estabeleceu funções rigorosas aos bispos: deviam reorganizar suas dioceses e garantir o bom preparo dos párocos para que esses também garantissem que todos os fieis assistissem às missas e recebessem os sacramentos, isto é, recebessem a devida assistência religiosa (APOSTOLADO, s/d, $3^{\circ}$ Período, Sessão XXIII, p. 09). Não por outra razão, Michel Mullett considerou que

\footnotetext{
os bispos foram os agentes indispensáveis da Contrarreforma; o Concilio de Trento foi em grande parte o seu concílio e eles tiveram como tarefa levar a cabo as suas decisões em diversas regiões da Europa. A reforma sistemática dos bispados, paróquia por paróquia, implicando a inspeção dos padres, o estabelecimento de escolas e seminários, a pregação e a administração dos sacramentos, constituiu o coração pulsante da Contrarreforma (MULLETT, 1985, p. 17).
}

Além de atuarem na formação dos sacerdotes católicos e na elaboração de textos auxiliares da evangelização, os bispos trabalharam para que missionários percorressem a Europa pregando o Evangelho e persuadindo sua audiência a aderir ou a retornar ao catolicismo. Porém, do mesmo modo que ostentavam as festas e os ritos católicos para uma persuasão suave, recorriam, onde podiam, à queima de livros, ao policiamento dos comportamentos através da confissão e à penitência em público para eliminar costumes e práticas religiosas que traziam reminiscências pagãs, judaicas ou protestantes. Atuando de modo semelhante na América, Ásia e África, esses missionários garantiam a 
expansão do catolicismo e sua defesa, projeto fortemente estimulado pelas monarquias ibéricas que lançaram mão da evangelização como instrumento de construção de seus impérios (SABEH, 2014, pp. 181-205; e SABEH, 2009, pp. 08-39).

Como se observa, a execução da Reforma Católica dependia, fundamentalmente, da associação dos poderes dos bispos, das monarquias católicas e, principalmente, de instituições religiosas capazes de defender e propagar o catolicismo. Entre elas estavam o Santo Ofício da Inquisição e as ordens religiosas, notadamente da Companhia de Jesus, que exerceu um papel singular nesse processo.

No início do no século XIII, o Tribunal do Santo Ofício foi criado pela Igreja Católica de Roma para combater a heresia dos albigenses. Uma vez combatida a heresia, o Tribunal foi extinto. Em fins do século XV, entretanto, o surgimento de novas heresias urgiu a necessidade do seu restabelecimento, principalmente na Península ibérica, composta por monarquias onde o catolicismo oferecia a base de uma identidade coletiva e, sobretudo, política. Nelas, como explica António Manoel Hespanha, o Direito, mais do que estabelecer uma intervenção normativa para disciplinar as condutas desviantes, voltava-se ao fomento da figura do rei enquanto dispensador da justiça, ou seja, era dirigido a uma intercessão simbólica na sociedade de monarquia corporativa (1989, pp. 03-11).

Em 1481, então, a Inquisição foi restaurada na Espanha e, em 1536, Portugal oficializou o seu funcionamento no intuito de manter a "ordem religiosa e social por meio da correção de delinquentes e pecadores" (PIERONI, 2000, p. 12). Era uma perfeita associação entre as Coroas ibéricas e a Santa Sé, expressas nas disposições legais de punição, que marcaria uma ruptura entre a Inquisição Medieval e a Moderna, já que, "pela primeira vez, assistia-se ao estabelecimento de uma ligação formal entre a jurisdição eclesiástica e a jurisdição civil” (BETHENCOURT, 2000, p. 18).

O intuito de tal associação? Perseguir os hereges.

A vigilância contra os hereges, que recorria ao castigo e à catequização, caracterizou a atuação da Inquisição do Santo Ofício como uma instituição responsável por reintegrar à sociedade católica os seus dissidentes. Referindo-se à atuação do Santo Ofício da Inquisição, Geraldo Pieroni destacou que "o motivo essencial que justificava a punição daqueles que infringiam a lei divina era a salvação de suas almas, ainda que para isso fosse necessário excluí-los do corpo social" (2000, p. 12) com o banimento. 
Era mais um instrumento salvacionista da Igreja Católica no embate reformista do catolicismo.

No que diz respeito à Companhia de Jesus, o salvacionismo, como veremos, marcou profundamente a atuação dos seus membros. Esta ordem, afinal, surgiu no mesmo processo que pedia medidas de proteção e de propagação da fé católica frente ao avanço luterano. Foi exatamente este o motivo que levou o papa que convocou o concílio de Trento a sugerir a fundação de congregações religiosas que trabalhassem a favor do fortalecimento moral da Igreja e da autoridade papal e que, principalmente, se dedicassem à salvação dos mortais.

\section{Uma nova ordem religiosa: a criação e a aprovação da Companhia de Jesus}

Em sua autobiografia, Inácio de Loyola - o fundador da Companhia de Jesus nos conta que ele era oficial do exército castelhano quando, em 1521, foi atingido gravemente na perna enquanto comandava uma guarnição de defesa contra os ataques franceses na cidade de Pamplona. Para não ficar coxo, passou por intervenções cirúrgicas que lhes exigiram um longo período de repouso. $\mathrm{Na}$ casa dos pais, passou a maior parte do tempo na biblioteca, onde entrou em contato com obras religiosas que tratavam da vida dos santos, principalmente a Fábula Dourada, de Jacopo da Voragine; e a Vida de Cristo, de Ludolfo da Saxônia. Estes textos eram obras inspiradas na Devotio Moderna, movimento religioso, como dito, que sugeria a meditação, a interiorização dos preceitos religiosos e a difusão do cristianismo pela multidão leiga para a purificação e salvação da alma do pregador. Eles despertaram a vocação religiosa do militar que, recuperado, iniciou a peregrinação aos lugares santos do cristianismo. $\mathrm{Na}$ viagem para o monastério beneditino de Montserrat, na Catalunha, Loyola decidiu abandonar definitivamente a espada e trocá-la por um cajado e uma roupa de peregrino (LOYOLA, 1952, pp. 23-45).

Neste monastério, o ex-militar entrou em contato com outra obra que sugeria a prática de uma espiritualidade inspirada na Devotio Moderna: o Livro de Exercícios para a vida espiritual do abade Cisneros, que propunha a realização de dez dias de meditação como preparação para a confisssão, exigência do autor para que o noviço vestisse o hábito beneditino. De Montserrat Loyola foi para Manresa, onde, baseado nos 
exercícios de Cisneros, iniciou a redação dos seus Exercícios Espirituais, produto de sua conversão pautada nos princípios da Devotio Moderna (LOYOLA, 1952, pp. 46$78)$.

Nascia, assim, mais um manual devoto para a prática de exercícios diários de oração com a finalidade de purificar o coração em busca da santificação pessoal, conceito do movimento religioso em questão. Dirigido ao público em geral, os Exercícios Espirituais preparavam o devoto à conversão, já que Loyola difundiu, neste texto, que a alma se convertia para a vida santa quando estivesse pronta para a Graça e livre de pecados. Esta preparação exigia quatro semanas de práticas espirituais, ou seja, os exercícios que Loyola definiu como

(...) qualquer modo de examinar a consciência, de meditar, de contemplar, de orar vocal e mentalmente, e outras operações espirituais (...). Assim como passear, caminhar e correr são exercícios corporais, chamam-se exercícios espirituais diversos modos de a pessoa se preparar e dispor para tirar de si todas as afeições desordenadas. E, depois de tirar estas, buscar e encontrar a vontade divina na disposição de sua vida para sua salvação (LOYOLA, 2000, pp. 09-10).

Esboçada a primeira versão do seu manual de salvação, Inácio de Loyola continuou sua peregrinação até Jerusalém, de onde se dirigiu para Barcelona em 1524. Ali iniciou a pregação dos Exercícios Espirituais e chamou a atenção dos inquisidores porque não tinha a formação necessária para tal, embora Inácio tivesse ingressado já nas Universidades de Alcalá e Salamanca. Após 64 dias de prisão foi absolvido porque a doutrina que pregava era considerada ortodoxa, no entanto, foi orientado pelo Santo Ofício a terminar sua formação antes de difundi-la. Foi assim que em 1528 o futuro santo católico foi para Paris determinado a concluir seus estudos em Teologia (LOYOLA, 1952, pp. 79-111).

Foi na França que Inácio reuniu um grupo de praticantes dos seus Exercícios Espirituais. Pedro Fabro, Francisco Xavier, Diogo Laines, Afonso Salmeron, Simon Rodrigues e Nicolau Bobadilha respiravam o ar humanista da cidade e, também, as ideias da Devotio Moderna vindas dos Países Baixos em fins do século XIV. Influenciados pelo autor dos Exercícios Espirituais, os amigos decidiram ir para a Terra Santa para converter os turcos. No dia 15 de agosto de 1534 fizeram voto na capela de Nossa Senhora, em Paris, de levar uma vida à semelhança da que Cristo ensinara. De acordo com Serafim Leite, 
(...) organizaram a sua vida espiritual de maneira a dar eficácia aos seus propósitos: voto de castidade, voto de pobreza, voto de ir em peregrinação a Jerusalém e ocupar a vida e forças na salvação do próximo, administração dos sacramentos da confissão e comunhão, pregação e celebração da missa, tudo sem estipêndio (LEITE, 1938, p. 05).

Loyola e seus companheiros não conseguiram levar a cabo a viagem à Terra Santa porque a Igreja censurou o desejo de peregrinação do grupo que se designava como pertencente à Companhia de Jesus. Porém, a nova sociedade religiosa começou a ganhar adeptos e, ainda alimento o desejo de ir a Jerusalém, em 24 de junho de 1539 seus membros redigiram a Fórmula do Instituto e entregaram o documento ao papado para que fosse analisada e aprovada a criação de uma nova ordem religiosa. ${ }^{8}$

Fica evidente, então, que foi o anseio de converter os turcos que levou Loyola a fundar a Companhia de Jesus. E justamente por isso, os historiadores Jonathan Wright e John O’Malley afirmaram que a ordem não foi criada para servir à Reforma da Igreja romana, ou mais particularmente à Contrarreforma. Em suas análises da Fórmula do Instituto, os pesquisadores não encontraram menção à ameaça protestante. De acordo com Wright,

ainda em 1540 Loyola e seus primeiros companheiros não estavam especialmente interessados em liderar os encargos da Contrarreforma. Não viam a desordem das duas décadas anteriores em termos estritamente doutrinários, mas sim como sintoma de mal-estar e crise moral generalizados. Visavam a uma renovação espiritual, uma purificação das almas, queriam corrigir a ignorância da doutrina, um expurgo dos pecados e da superstição. A espiritualidade que adotaram não foi concebida como resposta à heresia protestante, estava firmemente enraizada na tradição medieval da devotia moderna (WRIGHT, 2006, p. 32).

De igual maneira, O’Malley observou que

Não há necessidade de acentuar que a Reforma [Protestante] influenciou a
imagem da Companhia de Jesus, que de fato é frequentemente descrita como
tendo sido fundada precisamente para opor-se ao protestantismo. Esta
descrição, obviamente, erra o alvo. Em Paris, os companheiros
testemunharam as incursões do "luteranismo" dentro da capital francesa, mas
não utilizaram nada do que entendiam serem os principais pontos do novo
movimento. Embora consciente como estavam da Reforma, esta não exerceu
nenhuma influência palpável sobre o futuro que então delinearam para si
mesmos e assim fizeram poucas referências a isso quando descreveram seus

\footnotetext{
${ }^{8}$ Sobre o momento da vida de Inácio de Loyola que culminou na fundação da Companhia de Jesus ver, além da autobiobrafia de Loyola, LEITE, 1938, pp. 03-17; e O’MALLEY, 2004, pp. 45-84.
} 
anos em Paris. Quando, em 1534, assumiram o voto de passar algum tempo do ministério num lugar distante, voltaram seus olhares a Jerusalém e não a Wittenberg.

(...) Ao olharmos hoje para aquelas origens, ficamos impressionados tanto com as semelhanças entre esses dois fenômenos quanto com as diferenças reconhecidamente profundas. Em todo caso, embora a Companhia de Jesus tivesse uma história muito diferente, teria vindo à existência mesmo se a Reforma não tivesse acontecido, e não pode ser definida primeiramente em relação à mesma. Em muitas partes do mundo, o impacto direto da Reforma sobre os jesuítas varia do mínimo até o não-existente (O’MALLEY, 2004, pp. 36-37).

Perspicazes em suas análises, esses historiadores sensivelmente identificaram que a Reforma Protestante não havia tomado, no ato da criação da Companhia de Jesus, o vulto que pouco tempo depois tomaria e, por isso mesmo, abalaria as estruturas não só religiosas, mas sobretudo políticas do Velho Continente. Embora o papado já sentisse que as ideias luteranas poderiam constituir em uma séria ameaça para a Igreja de Roma, os católicos mais fervorosos não se preocupavam ainda em combatê-las, mas em renovar uma espiritualidade em crise. E é sugestivo que Loyola e seus amigos não tenham se preocupado com o jovem Lutero e sim desejassem peregrinar a Jerusalém, porque recuperar a Terra Santa através da pregação significava recobrar uma identidade religiosa do cristianismo primitivo que se baseava,essencialmente, na difusão dos ensinamentos do Cristo, tal como Ele recomendou a seus apóstolos: “ide, pois, e ensinai a todas as nações" (BÍBLIA, N.T. Mt., 28, 19).

No entanto, é necessário fazermos o exercício de diferenciar dois processos ligados ao nascimento da Companhia de Jesus enquanto uma instituição reconhecida pela Igreja Católica: sua criação por Loyola e seus companheiros e sua aprovação pelo papado.

Ignácio Iparraguirre comenta que a Companhia de Jesus foi confirmada pela Santa Sé em um momento em que a cúria romana pensava mais em extinguir ordens religiosas do que criar novas devido ao estado moral deplorável de muitos conventos europeus. A Fórmula do Instituto era um documento similar às Regras das ordens medievais, isto é, um documento que estabelecia o conjunto de princípios que regularia a vida dos adeptos da Companhia de Jesus. Depois de entregue por Loyola ao papado, o documento foi analisado por uma comissão de cardeais estabelecida para a Reforma Católica que, para além de lutar contra o protestantismo, discutia medidas amplas para a renovação do catolicismo. Inicialmente, a comissão deu alguns pareceres negativos 
quanto a aprovação da nova ordem religiosa, principalmente porque não estavam claros os aspectos relativos à possibilidade dos jesuítas aplicarem os sacramentos. Iniciou-se, então, um longo debate para ajustar os fundamentos da nova ordem religiosa.

O fato é que este debate contou, além das posições de teólogos, com recomendações positivas de D. João III, Carlos V e Francisco I com relação à sua aprovação e funcionamento. Na ocasião, esses monarcas representavam o bloco político mais poderoso da Europa e do mundo ocidental e, particularmente Carlos V, já havia iniciado um vastíssimo programa evangelizador na América. ${ }^{9}$ Assim, em 27 de setembro de 1540, o funcionamento da Companhia de Jesus foi aprovado através da bula Regimini Militantis Ecclesiae.

O texto da Fórmula subsidiou a redação da bula que aprovou o funcionamento da Companhia de Jesus. A análise desses documentos demonstra que a Igreja Católica fez algumas ressalvas ao seu funcionamento, que se expressam, evidentemente, nas modificações feitas no texto que Loyola entregou ao papado (IPARRAGUIRRE, 1952, pp. 341-367).

Essas ressalvas recaíam em questões doutrinais, notadamente sobre os sacramentos, como dito, para que não se apresentasse semelhança ao que pregava Lutero sobre este assunto. Mas, outras alterações foram mais sensíveis, como o sentido que se dava à finalidade da criação da Companhia de Jesus. Os dois documentos trazem o termo militare Deo sub vexillo crucis, que em português significa "soldado de Deus sob a bandeira da cruz". Mas, se para Loyola e seus companheiros a frase (na Fórmula do Instituto) significava a peregrinação à Jerusalém, para a Igreja (na Regimini Militantis Ecclesiae) era a sugestão de uma ordem militante que trabalharia na defesa e propagação da fé, como pedia o quadro de crise do século XVI. Não por outra razão, a bula enfatizou:

Saibam todos os membros da Companhia (...) que toda esta Companhia e cada um em particular, combate por Deus sob a fiel obediência ao Santíssimo Senhor nosso, o Papa, e aos outros Romanos Pontífices, seus sucessores. (...) Para maior humildade da nossa Companhia e perfeita mortificação de cada um e abnegação das nossas vontades, julgamos da maior importância que cada um de nós (...) se ligue por um voto especial (...) para proveito das

\footnotetext{
${ }^{9}$ Em 1542, dois anos após a aprovação da Companhia de Jesus pela Santa Sé, também D. João III iniciou esse programa evangelizador em seus domínios ultramarinos. Até 1580, os jesuítas tiveram a exclusividade de missionação nos domínios portugueses da Ásia, África e América. Ver SABEH, 2009, pp. 27-39.
} 
almas e propagação da fé. E assim fiquem obrigados, quanto estiver na nossa mão, a ir sem demora para qualquer região aonde nos quiserem mandar, sem qualquer subterfúgio ou escusa, quer nos enviem para entre os turcos ou outros infiéis, que habitam mesmo que seja nas regiões que chamam Índias, quer para entre hereges ou cismáticos, quer ainda para junto de quaisquer fiéis (CARTA, 1540, pp. 24-25).

Compreende-se, portanto, que não foi a finalidade da criação da Companhia de Jesus que serviu à Reforma Católica, mas sim a disposição dos seus fundadores em matéria de renovação da fé. Uma vez dispostos a ganhar o mundo para pregar o Evangelho, os jesuítas atendiam às aspirações da Igreja e dos monarcas católicos de defender e propagar o catolicismo romano.

Este ânimo, incomum para a sua época, era o resultado da inovação da vida monástica proposta por Loyola. No Exame, um manual que ditava quem devia entrar na Companhia e o que era a ordem até que ficassem prontas suas Constituições, Loyola afirmou que "o fim da Companhia não é somente ocupar-se, com a graça divina, da salvação e perfeição das almas próprias, mas, com esta mesma graça, esforçar-se intensamente por ajudar a salvação e perfeição das do próximo" (LOYOLA, 1997, p. 40). ${ }^{10}$

Este trecho do Exame foi interpretado por Serafim Leite como a dupla finalidade da aprovação da Companhia de Jesus: a individual e a apostólica, a característica mista de uma ordem que não seria apenas contemplativa, mas também ativa. A salvação própria viria com a prática dos Exercícios Espirituais, e a do próximo, com a evangelização e aplicação dos sacramentos. Daí o historiador considerar que Loyola estabelecera um novo conceito para a vida religiosa: enquanto a inserção em uma ordem religiosa presumia o afastamento do mundo para a imitação da vida de Jesus, como acontecia nas ordens medievais,

Santo Inácio integra[va] sua ordem no mundo e faz[ia] dela uma campanha para a conquista do mundo", tal como Jesus apresentou-se: "como Rei à conquista do mundo sobrenatural, [que] convida[va] todos os homens de boa vontade a participar desta conquista (LEITE, 1938, p. 15).

Esta, portanto, era a característica "moderna" da Companhia de Jesus, que combinava com outras ainda medievais. Seu fundador inovava a vida religiosa para

\footnotetext{
${ }^{10}$ Por ser o Exame um documento informativo voltada a oferecer aos interessados em ingressar na ordem uma visão geral da Companhia de Jesus, transformou-se na introdução das Constituições com o título Primeiro Exame Geral que se há de propor a todos os que pedirem a admissão na Companhia de Jesus.
} 
levar o cristianismo pela palavra e não pela espada aos muçulmanos em Jerusalém. De qualquer forma, seu intento salvacionista constituía a modernidade de sua ordem, e este era um dos elementos que permeava a Reforma Protestante e a Contrarreforma. Certamente, nisto residiu o interesse da Igreja Católica em aprovar o funcionamento da nova ordem religiosa.

\section{Considerações finais}

Nas reformas religiosas da Europa dos Quinhentos, a pauta das discussões entre os teólogos e eruditos, reformados ou não, era a salvação da humanidade. Como ela poderia ser salva? Qual igreja, sacramentos e sacerdotes estavam mais aptos para garantir a sua redenção?

A reação católica ao protestantismo, como vimos, residiu na asseguração da posição salvífica da Igreja de Roma. E é sintomático, nesse sentido, que o Santo Ofício e a Companhia de Jesus tenham oferecido amparo devoto a este fim. Disposta a ganhar o mundo, esta última instituição foi organizada para garantir a conversão de milhares de almas para além das fronteiras da Europa. Mas, se a Fórmula do Instituto indicava a conversão dos turcos, a bula Regimini Militantis Ecclesiae transformava a nova ordem religiosa em um instrumento de defesa e difusão do catolicismo na Europa e no Novo Mundo. Ao aprovar o funcionamento da ordem, e exigir que seus membros "sem qualquer subterfúgio ou escusa" (CARTA, 1540, p. 24) embrenhassem-se nas Índias para a evangelização dos seus naturais, a Igreja oferecia mais um instrumento à disposição dos monarcas católicos imbuídos também dessa tarefa. E não parece ter sido por outra razão que os reis da Espanha e de Portugal tenham utilizado as mesmas instituições da Contrarreforma na construção e manutenção de seus impérios coloniais, como a Inquisição e as ordens religiosas. E é sabido que a Companhia de Jesus realizou um papel de destaque nesse processo, principalmente nos domínios portugueses, onde atuou com mais afinco do que na América espanhola. Talvez isso explique porque a ordem nasceu como uma instituição poderosa que, além de privilégios, se valia de 
mecanismos políticos para levar a cabo suas atividades nos quatro continentes em que atuou já na sua primeira década de funcionamento. ${ }^{11}$

Assim, ao fazermos o exercício de diferenciar os dois processos que institucionalizaram a Companhia de Jesus, percebe-se que a criação e a aprovação da nova ordem religiosa apresentaram, sem dúvida nenhuma, sentidos diferentes. Entretanto, considerando o ambiente religioso do meio onde ela foi criada, não nos resta dúvidas, também, de que se a criação da ordem jesuítica não foi pensada para dar amparo à Contrarreforma, a sua aprovação pela Santa Sé o foi.

\footnotetext{
${ }^{11}$ A ordem iniciou suas atividades em Portugal em 1540, de onde foi levada para a Ásia em 1542, para a África em 1547 e para a América em 1549. Já na Espanha a Companhia de Jesus iniciou suas atividades em 1543, de onde foi levada para a América espanhola em 1566. Sobre a atuação da ordem nos impérios ibéricos nos séculos XVI e XVII ver, na íntegra, SABEH, 2009 e SABEH, 2014.
} 


\section{Referências}

Fontes

APOSTOLADO Veritatis Splendor (org.). Documentos do Concílio Ecumênico de Trento. $1^{\circ}$ Período (1545-1547); $2^{\circ}$ Período (1551-1552); $3^{\circ}$ Período (1562): Bula Convocatória do Concílio e Sessões de I a X; Bula de Reinstalação do Concílio e Sessões de XI a XVI; Bula de Reinstalação do Concílio, Sessões de XVII a XXV, Finalização do Concílio, Admoestações aos Padres, Confirmação do Concílio e Apêndices. Direção de Carlos Martins Nabeto e tradução de Dercio Antonio Paganini. Disponível em http://www.veritatis.com.br/doutrina/documentos-da-igreja. Acesso em 21/12/2012.

CARTA Apostólica Regimini militantis Ecclesiae, dada em 27 de setembro de 1540, ou Fórmulas do Instituto da Companhia de Jesus aprovadas e confirmadas pelo Sumo Pontífice Paulo III. In: LOYOLA, Inácio de (1491-1556). Constituições da Companhia de Jesus e normas complementares. Anotações da Congregação Geral XXXIV (1995). São Paulo: Edições Loyola, 1997.

LOYOLA, Inácio de (1491-1556). Constituições da Companhia de Jesus e normas complementares. Anotações da Congregação Geral XXXIV (1995). São Paulo: Edições Loyola, 1997.

Exercícios Espirituais. São Paulo: Edições Loyola, 2000.

Autobiografia. In: IPARRAGUIRRE, Ignacio; DALMASES, Candido de (orgs.). Obras Completas de San Ignacio de Loyola. Edicion Manual. Madrid: La Editorial Catolica, 1952.

RABELAIS, François (1490-1553). Gargântua e Pantagruel. Belo Horizonte: Itatiaia, 2003.

ROTERDÃ, Erasmo de (1465-1536). Elogio da Loucura. 8 ed. São Paulo: Atena, 1959.

\section{Bibliografia}

ASSUNÇÃO, Paulo de. Negócios jesuíticos: o cotidiano da administração dos bens divinos. São Paulo: Editora da Universidade de São Paulo, 2004.

BETHENCOURT, Francisco. História das Inquisições: Portugal, Espanha e Itália - séculos XV-XIX. São Paulo: Companhia das Letras, 2000.

BÍBLIA. Português. Bíblia Sagrada. 126 ed. São Paulo: AVE-MARIA Edições, 1999.

CALMON, Pedro (1902-1985). História do Brasil. v. III.2 ed. Rio de Janeiro: Livraria José Olympio, 1963.

DELUMEAU, Jean. A civilização do Renascimento. Lisboa: Edições 70, 2004.

La Reforma. Barcelona: Labor, 1967.

EISENBERG, José. As missões jesuíticas e o pensamento político moderno: encontros culturais, aventuras teóricas. Belo Horizonte: Editora UFMG, 2000.

FEBVRE, Lucien. O problema da incredulidade no século XVI: a religião de Rabelais. São Paulo: Companhia das Letras, 2009.

FRANCO, José Eduardo; TAVARES, Célia Cristina. Jesuítas e Inquisição: cumplicidades e confrontações. Rio de Janeiro: EdUERJ, 2007.

GREEN, Vivian H. H. Renascimento e Reforma. Lisboa: Dom Quixote, 1991.

GROSSI, Vitorino; SESBOÜÉ, Bernard S.J. Graça e justificação: do testemunho da Escritura ao fim da Idade Média. In: SESBOÜÉ, Bernard S.J. (dir.). História dos dogmas: o homem e sua salvação. Tomo 2. São Paulo: Edições Loyola, 2003a.

Graça e justificação: do concílio de Trento à época contemporânea. In: SESBOÜÉ, Bernard. S.J. (dir.). História dos dogmas: o homem e sua salvação. Tomo 2. São Paulo: Edições Loyola, $2003 b$.

IPARRAGUIRRE, Ignácio. Introducción para las Constituciones de la Compañía de Jesús. In: 
IPARRAGUIRRE, Ignacio; DALMASES, Candido de (orgs.).Obras Completas de San Ignacio de Loyola. Edicion Manual. Madrid: La Editorial Catolica, 1952.

HESPANHA, António Manoel. Da “Justitia” à "Disciplina”: textos, poder e política no Antigo Regime. In: Boletim da Faculdade de Direito de Coimbra. Estudos em homenagem ao professor doutor Eduardo Correia. Coimbra: Universidade de Coimbra, 1989.

HOLANDA, Sérgio Buarque de (dir.). História Geral da Civilização Brasileira. A época colonial: do descobrimento à expansão territorial. v. I. Tomo I. 16 ed. Rio de Janeiro: Bertrand Brasil, 2008.

(dir.). História Geral da Civilização Brasileira. A época colonial: administração, economia, sociedade. v. II. Tomo I. 10 ed. Rio de Janeiro: Bertrand Brasil, 2003.

LADARIA, L. F. A criação do céu e da terra. In: SESBOÜÉ, Bernard S.J. (dir.). História dos dogmas: o homem e sua salvação. Tomo 2. São Paulo: Edições Loyola, 2003.

LEITE, Serafim. História da Companhia de Jesus no Brasil. Tomo I. Lisboa: Livraria Portugália; Rio de Janeiro: Civilização Brasileira, 1938.

MUlletT, Michael. A Contra-Reforma e a Reforma Católica nos princípios da Idade Moderna europeia. Lisboa: Gradiva, 1985.

O’MALLEY, John W. Os primeiros jesuítas. São Leopoldo: Editora UNISINOS; Bauru: EDUSC, 2004.

PIERONI, Geraldo. Os excluídos do Reino: a Inquisição portuguesa e o degredo para o Brasil Colônia. Brasília: Editora da Universidade de Brasília; São Paulo: Imprensa Oficial do Estado, 2000.

REALE, G.; ANTISERI, D. História da filosofia: do humanismo a Kant. v. II. São Paulo: Paulus, 1990.

SABEH, Luiz Antonio. Colonização salvífica: os jesuítas e a Coroa portuguesa na construção do Brasil (1549-1580). Dissertação (Mestrado em História) - Programa de Pós-Graduação em História Universidade Federal do Paraná, Curitiba, 2009.

Semeando um novo mundo: a Companhia de Jesus e a administração Habsburgo no Brasil. Tese (Doutorado em História) - Programa de Pós-Graduação em História - Universidade Federal do Paraná, Curitiba, 2014.

SIQUEIRA, Sonia A. A Inquisição. São Paulo: FTD, 1998.

SKINNER, Q. As fundações do pensamento político moderno. São Paulo: Companhia das Letras, 1996.

TAVARES, Célia Cristina da Silva. Jesuítas e inquisidores em Goa: a cristandade insular (1540-1682). Lisboa: Roma Editora, 2004.

VAINFAS, Ronaldo. Trópico dos pecados: moral, sexualidade e Inquisição no Brasil. Rio de Janeiro: Nova Fronteira, 1997.

WRIGHT, Jonathan. Os jesuítas: missões, mitos e história. Rio de Janeiro: Ediouro, 2006.

Recebido: $14 / 11 / 2015$

Received: 11/14/2015

Aprovado: 03/12/2015

Approved: $12 / 03 / 2015$ 